\title{
A REAL REACTION ANYWAY
}

I see you trudging to class each day, and it takes patience to watch you. Each day is farther away

from birth,

that wilted leg

and the rest

of your flabby body. Your body-you have decided your body can never be your body. That is why

You take our time with the impudence one expects of intelligent cripples. Actually you are not humble, and since sex is denied forever you appeal to me with your eyes. Your body is not your body at all, you say, can never be your body. That is why you stutter

To make us make it out, and are soft forcing us to listen to you. Each day I'm farther away from you, the "true you", because you disgust me with your mind. Your body-what would your body matter if only your fine points were finer. There is more in life

Than physical well-being. I am quite unhappy often. Yet I can walk home faster

than you can

buy a wheelchair.

Depressed by love,

the nature of it, especially when successful, I walk

freely, but my heart is crippled.

There is a joke. It goes like this.

A man was a gimp in one arm, gnarled like a Mongol tree, and said, Oh God

make my bad arm

be like my good

arm, and then the grotesque teller of the tale gimps

both his perfect arms to show what God hath wrought. 
Birth defects of the spirit are not to be expected, and, as I see you, a solitary miss, breaking up the ground by breaking up the hill, I do not credit you with spiritual agony. There is less to hurt you in your life. Your leg is not seductive.

You will not be seduced.

The human things you miss should make you very happy. I can't believe you want to love. I can't believe you'd want to trade a measily inconvenience for all the pain I have. I had a dream

You could never have. I dreamt you were more crippled than your wildest shameful flourish, depressed by every step you took, not reconciled at all, whereas you are reconciled, and you, reduced to a ball of hair with props, were rolling up the stairs, quite feminine

In your bitching. On an inclined plane I stood leaning out above you. I said to my friend, After all, there is worse suffering than physical suffering. You grumbled like the dog you were, and you and your friend leading you went on

Upstairs complaining about me. Later I was told I was your only pleasure, that it had been decided I was to be your only pleasure for the evening to reconcile you, a mercy mission of the flesh. And then it dawned upon me, and I started 
Screaming. Perhaps there is no worse suffering than physical suffering, perhaps being crippled is the worst thing

in the world

that can happen

to anybody!

My body-I have decided that my body can never be your body.

I refuse you without waiting for I will have no withered girl,

And I will have no withered leg, and not a broken arm, no war shall make me unattractive,

no God shall

make us one

and cripple me

for you. For all your chance in Chaucer I wouldn't yield

a wisdom tooth, and I can't even like you. 